\title{
FERVET OPUS:
}

MILAN ZLOKOVIĆ AND ARCHITECTURE OF THE CITY

\author{
A B S T R A C T
}

This paper studies the competition project by the architect Milan Zloković for the Workers Housing Estate of the Kvarner Shipyards in Rijeka, ${ }^{1}$ 1947-8 (Radničko naselje Kvarnerskih brodogradilišta na Rijeci). The principal aim, in addition to presenting this, until now unpublished and largely unknown work of the architect, is to discuss its propositions against the historical and socio-political context of the momentous change of paradigms following the end of World War Two. The paper explores how, through a programmatic shift towards the issues of urbanism, Zloković subtly adapted the design vocabulary of the interwar modern architectural form to the new cultural, political and social circumstances of the postwar years. 
And now they ascended the Hill, which hangs over a great Part of the Town, and from above surveys its opposite Towers. Here Æneas admires the stately Buildings, where Cottages once stood: He admires the lofty Gates, the Hurry and Bustle of the Town, and the Magnificence of the Streets. The Tyrians warmly ply the Work: Some are extending the Walls, and raising the Tower, or pushing along unwieldy Stones: Some mark out the Ground for a private Building, and enclose it with a Trench: Some choose a Place for the Courts of Justice, for the Magistrates Halls, and the venerable Senate. Here some are digging Ports: There others are laying the foundations of lofty Theatres, and hewing huge Columns from the Rocks, the lofty Decorations of future Scenes. Such their Toil as in Summer's Prime employs the bees amidst the flowery Fields under the warm Sun, when they lead forth their fall grown Swarms; or when they lay up the liquid Honey, and distend the Cells with sweet Nectar; or when they disburden those that come Home loaded, or, in formed Battalions, drive the inactive Drones from the Hives. The Work is hotly plied, and the fragrant Honey smells strong of thyme / Fervet opus, redolentque thymo fragrantia mella.

Virgil (Publius Vergilius Maro), Aeneid ${ }^{2}$

\section{INTRODUCTION}

When the architect Milan Zloković chose to use the syntagm fervet opus as the identification code for a competition entry, a particular image must have formed in his mind's eye, the vision of a city, not dissimilar to the one Virgil described in the first book of his epic poem the Aeneid. Quoted in the epigraph as translated into English prose, Virgil writes of the construction of a magnificent city in Carthage, which the hero Aeneas beholds from the hill above it. In his verses, the poet represents the labor, skill and assiduity of the Carthaginian builders, by the industry and art with which bees carry on their works. Fervet opus, work boils, writes Virgil, and the city is being founded in the landscape where once only country cottages stood and fragrant thyme saturated the air. Fervet opus, notes Zloković on his competition drawings for the Workers Housing Estate of the Kvarner Shipyards in Rijeka, ${ }^{3}$ envisaging a new workers city in an analogous Mediterranean landscape. (Fig. 1) It may well be that Zloković metaphorically used the great Roman poet's verse to denote the sweet air of the natural setting, but there is more to this particular naming of the project than meets the eye. 


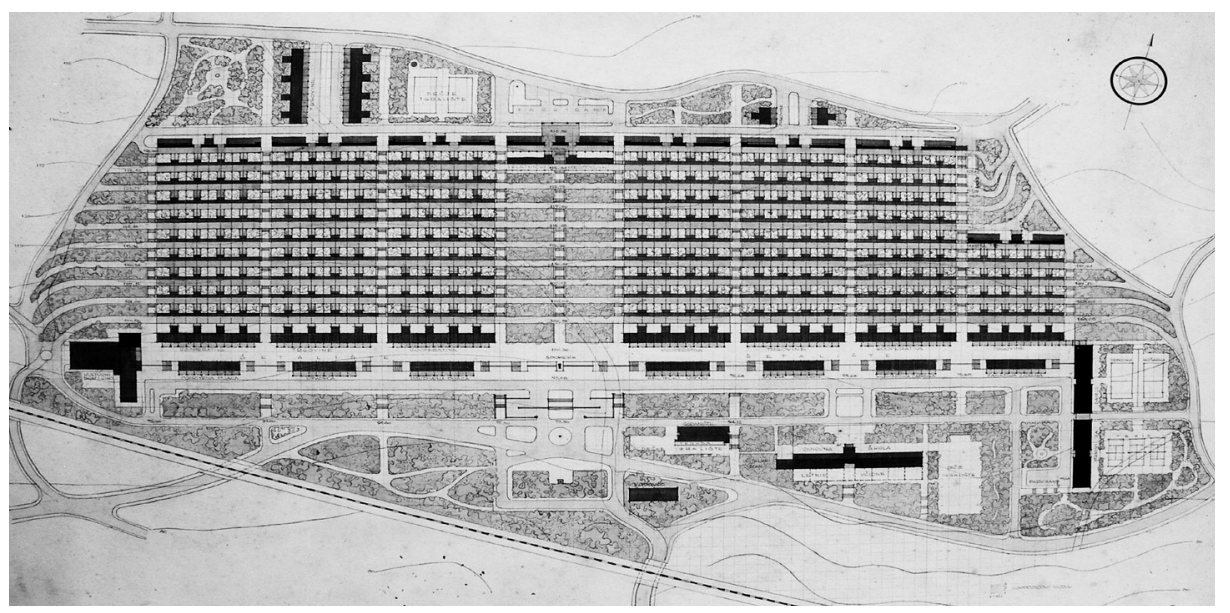

Figure 1

Milan Zloković, Workers Housing Estate of the Kvarner Shipyards in Rijeka, 1947-8, site plan

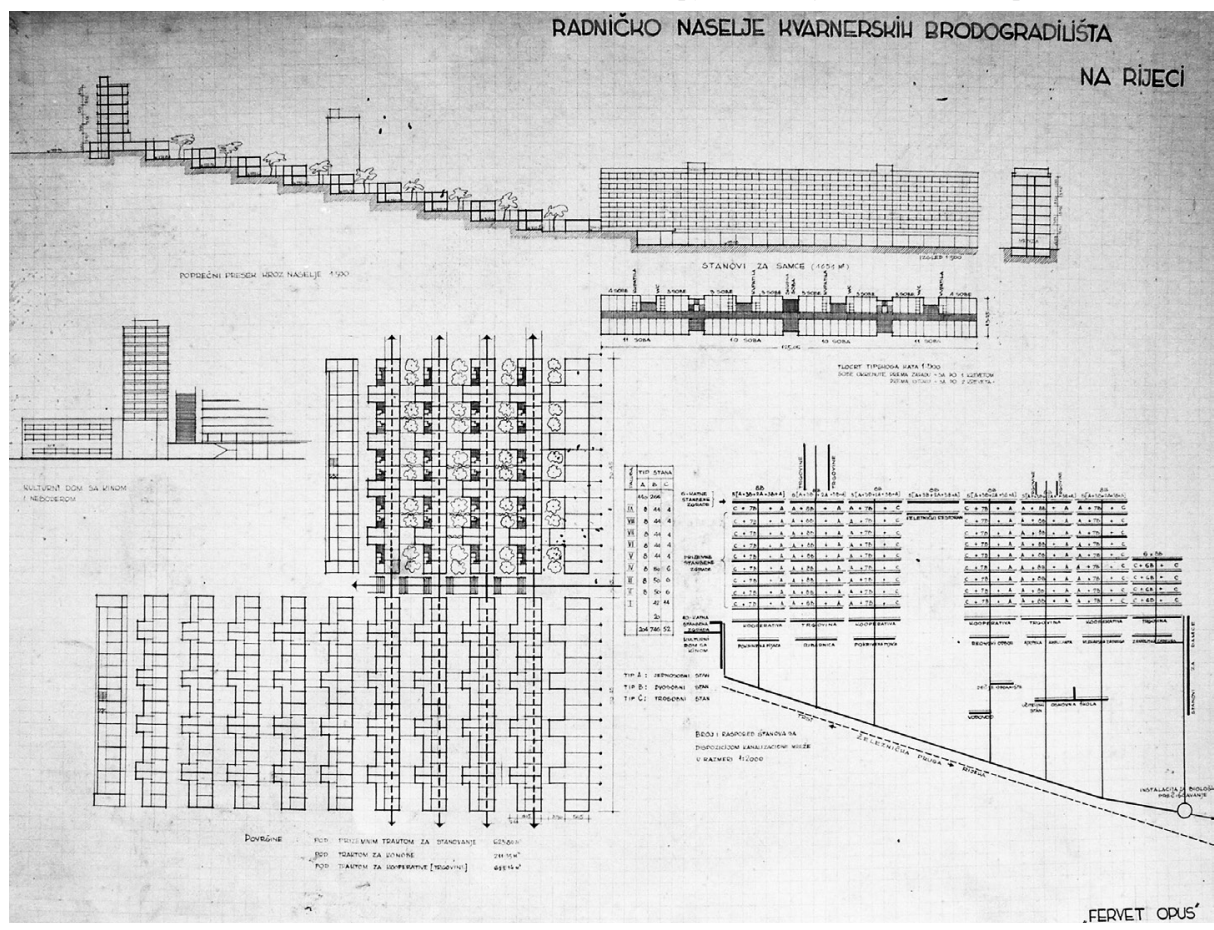

Figure 2

Zloković, Workers Housing in Rijeka, outline section and partial plan of the central housing area on decks 
Particularly relevant for understanding the intrinsic problem posed by this project, including its code, is the historical time of its inception following the end of World War Two, the time of momentous change of paradigms - historical, socio-political, cultural - and, pertaining to the subject of this research, urbanist. In the post-war years, Le Corbusier's tenet from the 1920 s, that the problem of the house is a problem of the epoch, is universally extended to the problem of housing. In that sense, Zloković's project clearly demonstrates the shift from the modernist problem of architectural object house or apartment building - to the question of housing and the concept of the modern city appropriate for the needs of the post-war period. Ravaged though Yugoslavia was by the war, rebuilding began immediately after the war ended, and planning and design for the new post-war world flourished, despite the general scarcity of funds to realize ambitious ideas. The period is marked by renouncing traditional urbanism and planning of new cities (New Belgrade being perhaps the most prominent), or new housing estates and colonies all over the country. Zloković's invoking the Roman poet's verse fervet opus might have reflected the atmosphere of fervent reconstruction of the country, but also the excitement of witnessing the new epoch of city building, comparable to the one Aeneas saw in Carthage. Even if far-flung, a Loosian sense of the Roman culture in Zloković's fervet opus coding can be traced. Loos claimed that the techniques of contemporary thinking are inherited from the Romans, and so is the social thinking, which enabled them to administer not only the city but the world. ${ }^{4}$ In his interpretation of Loos's understanding of the Romans, Massimo Cacciari argues that "[ $t]$ he 'Roman' is seen by Loos in terms of functionality and use. Its dimension is that of experience, of the temporal - and hence of social existence". ${ }^{5}$ And the context of the Roman project, ultimately is the res publica.

Zloković's project can be seen to be situated in this very register, it places at its centre, not the object of modern architecture, but the architecture of the city as its object and res publica as its objective. As a primarily urban planning scheme, the project is unique in Zloković's predominantly architectural opus, and as such it deserves special attention. However, it is the significance of the shift of techniques of thinking from architecture to urbanism, the shift from object to city, private to public, and individual to community, which is the principal reason to extract this project from the architect's work and to examine it more closely and in more detail. 


\section{THE CONTEXT OF SHIFTING BORDERS}

The competition in question was organized in the first years following the liberation of Yugoslavia in World War Two, when the city of Rijeka, an important port in the northern Adriatic, became part of the newly founded Federation. Historically, Rijeka (Fiume, Ital.) was ruled by the Austrian Habsburgs, established as a free port in 1720s, controlled in periods by Austrian, Croatian, and Hungarian administrations until 1870, when it came under direct rule by Budapest as the only Hungarian international port on the Adriatic. In the complex power division within the Austro-Hungarian Empire, the neighboring city of Trieste acted as major Austrian port in the Adriatic, ruled directly from Vienna. In accordance with such distribution of power and governance, in addition to the main rail line Vienna-Trieste (est. 1857), Rijeka was connected by rail line to Budapest in 1873 , with a lateral link to Trieste-Vienna line. After the demise of the Dual Kingdom, in the great powers brokering of both World War One allegiances and post-war appeasements, Rijeka was politically split between Italy and the Kingdom of Yugoslavia, as the Italian city Fiume and the Croatian/Yugoslav eastern part Sušak, with joint administration of the port facilities. In her travelogue through Yugoslavia of the 1930's, Rebecca West writes about this paradoxical division of the city:

[W] could cross the bridge over the river that leads from Sushak [Sušak] to Fiume. There we found a town that has the quality of a dream, a bad headachy dream ... hacked by treaties into a surrealist form. On a ground plan laid out plainly by sensible architects for sensible people, there is imposed another, quite imbecile, which drives high walls across streets and thereby sets contiguous houses half an hour apart by detour and formality. And at places where no frontiers could possibly be, in the middle of the square, or on a bridge linking the parts of a quay, men in uniform step forward and demand passports, minatory as figures projected into sleep by an uneasy conscience. ${ }^{6}$

Thus, after being ruled by varying and competing powers, absurdly divided by international treaties and finally occupied by the Third Reich, the city of Rijeka was only joined up and fully integrated in Yugoslavia after it was liberated from the German occupation on $3^{\text {rd }}$ May 1945 by Tito's partisans army. The city immediately became an important port, industrial and maritime centre of the new country. In 1946, for the first time since the fall of the Austro-Hungarian empire, Rijeka and Sušak were considered as a contiguous urban area and correspondingly treated by planners in the outline master regularization plan. 
This geographic-historical context is also relevant as the background to Milan Zloković's particular personal and family history and, consequently, his particular habit of mind. As is well known from his biography, Zloković was born in 1898 in the Italian city of Trieste, as a Serb originating from Boka Kotorska in Montenegro, and as a citizen of the multinational Dual Monarchy. ${ }^{7}$ At the demise of Austro-Hungarian army at the end of World War One, Zloković was interned in Rijeka where he subsequently crossed over and joined the Serbian army which took over the city briefly in 1918. Soon thereafter, he renounced the right to take Italian citizenship, left the parental home in Trieste and emigrated for good to the newly formed Kingdom of Serbs, Croats, and Slovenes. ${ }^{8}$ Zloković was, thus, at home in the context of shifting borders and unstable citizenships, disintegrating empires and the newly formed states, international treaties and division lines. In addition, Rijeka as maritime and coastal city must have been a familiar territory for the architect, and the ship building industry had a special significance for him. As I have argued in the past, his particular creative disposition originated from the deep appreciation of "the great trinity of the Mediterranean life: the sea, the ship, and the stone house", and the loyalty and sense of belonging he felt for the rationality and aesthetic of both ships and the architecture of the Adriatic coastal region, from Trieste and Rijeka in the North, to Boka Kotorska and the city of Ulcinj in the South. ${ }^{9}$

\section{THE PROJECT: WORKERS HOUSING ESTATE OF THE KVARNER SHIPYARDS IN RIJEKA}

The shipyards, for which the workers housing was planned, located in Brgudi area in the western part of Rijeka, were established in $1892 .{ }^{10}$ At the end of World War Two, the shipyards were completely dysfunctional, as the retreating German army destroyed every vital facility. Upon constitution of Yugoslav authorities in Rijeka, the shipyards were taken over and named "Kvarnerska brodogradilišta" (The Kvarner Shipyards). The reconstruction was rapidly undertaken so that by 1948 the work was partially resumed, while the yards had simultaneously been developed further with the orientation to building of a transoceanic merchant fleet in future. To mark the third anniversary of Rijeka's liberation, in 1948 the shipyards' name was changed into "Shipyard $3^{\text {rd }}$ May".

Zloković's competition project, thus, dates from the period 1946-8, i.e., the years when the war ravaged shipyards were thoroughly reconstructed and bore the name "Kvarnerska brodogradilišta" as noted on the drawings. This period in new Yugoslavia was marked by the planned economy and the first five-year 

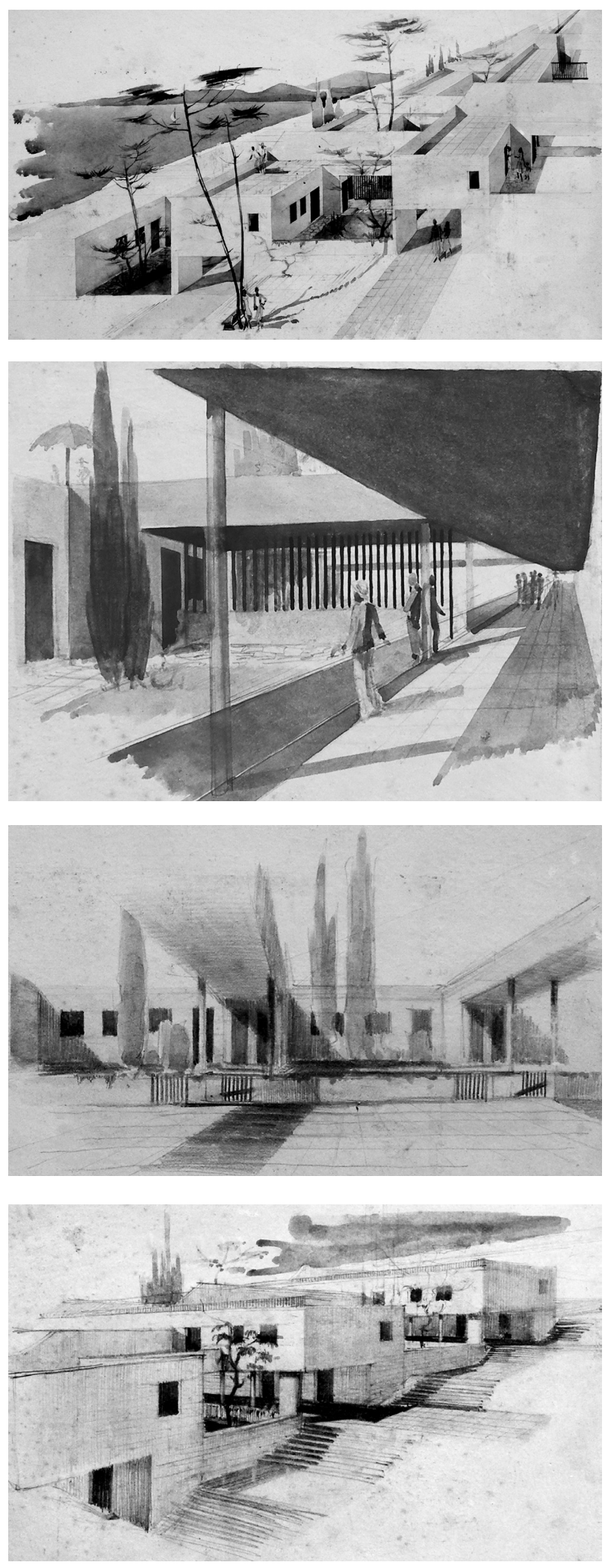

Figure 3

Zloković, Workers Housing in Rijeka, aerial view of cascading housing structure
Figure 4-5

Zloković, Workers Housing in Rijeka, views of the individual unit from the deck walkway

Figure 6

Zloković, Workers Housing in Rijeka, view of cascading units from transverse circulation stair 
plan of economic development, 1947-51. ${ }^{11}$ The competition program and its focus on workers housing adjacent to the related industry, reflects the general orientation of the plan, and its specific stipulations for both housing and public programs. The inclusion of the cinema in the workers housing estate, for instance, would directly ensue from the plan, as the development of cinematography and construction of cinemas was a priority in planning for the culture of the masses. It is, therefore, more likely that the project followed after the announcement of the five-year plan, i.e., that it dates between May, 1947 and May, 1948. ${ }^{12}$

The site of the workers housing of ca. 40ha in the hinterland of the Brgudi coastal area, is delineated by the Rijeka-Trieste railway line on its south perimeter. ${ }^{13}$ It slopes rather steeply from the highest part at $130 \mathrm{~m}$ above the sea level to $90-95 \mathrm{~m}$ at the site edge by the rail line. The estate was planned as a microreyon (micro district), i.e., residential complex for the population of some $6,000-8,000$ inhabitants, fully supported by social and commercial services. The typical program for microreyon corresponded to the administrative organization of local authorities of the period and the consequent organization of cities in reyons (districts) and housing estates - microreyons. In cities, the housing estates were considered the primary organizational units, which consisted of residential buildings and ambitiously planned public, commercial, and social facilities. As noted in previous researches, the ideological basis of such ambitious programming could be found in the socialist/communist objective to lessen and, eventually eliminate, the disparities between centre and periphery, as well as in the aim to increase the ratio of urban public areas in the socialist city planning. ${ }^{14}$ In concordance, Zloković's project proposes the cultural centre with 350 seats multi-purpose hall and 200 seats cinema, primary school and kindergarten, reyon council offices, shops, cooperatives, covered green market, fishmongers market, artisans shops, pharmacy, surgery, canteen and restaurant, all in addition to the residential program of 1,000 single floor apartment and garden units, 500 apartments in high-rise blocks, and accommodation for ca. 1,000 single persons in "singles hotel". ${ }^{15}$ The planning also provides for the open air children playgrounds, basketball, volleyball and tennis courts, green public areas and promenades, as well as infrastructure of roads, parking lots, water supply station and complete installation for biological recycling of waste water. Considered from the aspect of its program, the project represents a typical one for the period of the first five-year plan, and comparable to the microreyons planned in other parts of the country. Its singularity, I would contend, lays in its town planning concept which seems quite unique for the period and in its specific formal resolution. 
Zloković sets a spatial, three-dimensional grid thought of as a continuum which provides the absolute reference for both urban and architectural form. The main body of housing is organized in single floor individual units, which are distributed horizontally over the whole site, and stepped to accommodate the slope of the terrain. It is essentially a concept of multiplied generic form, a spatial system of individual units which combine in a unified field or structure defined by the grid. The grid - based on a compositional module of $7.8 \mathrm{~m}$, structural module $5.2 \mathrm{~m}$, and design module $1.3 \mathrm{~m}$ square - is laid over the slope of the terrain so that its third dimension organizes the volumetric and vertical movement. The grid is also valuable as it accommodates different dwelling typologies, while maintaining a general order. (Fig. 2)

While the horizontal arrangement of single floor units implies a continuous field on plan, the circulation or movement is organized through properties of the section, in a linear system interconnected with the volumetric organization. The scheme is, thus, best understood through sections or perspective sketches showing the interlocking of movement and volumetric composition. (Fig. 3) Longitudinal walkways on stepped "decks" are articulated through sectional properties of the units cascading down the slope of the terrain. The stepping section allows for the transverse decks to connect on level the ground floors of upper units with the roof terraces on the lower (Fig. 4 and fig. 5). Transverse movement up and down the cascades forms the stepped streets which delineate the grouping of units and connect them to public programs at the bottom of the section (Fig. 6) The interlocking of volume and movement is further elaborated in the articulation of mass and void, also by taking into account the Mediterranean geographic and climatic conditions, and culture of dense communal living. Lastly, the relation of mass to surface achieves a continuity which makes the system appear seamless. The individual unit is not perceptible per se, it is subsumed by the system, formally as well as functionally.

The planning also provides for housing in a number of six-floor buildings on the upper perimeter of the site, yet central to the scheme is the horizontal grouping of units and its configuration into a dense urban structure. Its compact arrangement over the middle ground dictates the overall organization of traffic and circulation around the perimeter and placement of all public programs along a promenade in parallel to the green buffer zone on the south boundary of the site.

The scheme rigidly enforces the geometric layout defined by the grid, it is a rationalist urbanism with no concessions to period realism of national in form, 
socialist in content. Here, form is abstract, pure modern and content is social, not necessarily socialist. Zloković produced this project in the context of the post-war reconstruction in the conditions of the socialist planned economy, clearly, as the design for the collective, and, in that, rendering of the collective subject is the central concept. Yet, this concept stands out from the general practice of the period, contrasting sharply with the dominant planning paradigm for socialist housing colonies, and the generally promoted collective dwelling models. The planning focuses on the question of the individual unit and its multiplication, and the changing relation between public and private spaces. It is a vision of a community of individuals and of dwelling practice addressing the radical change of property relations, and everyday patterns of habitation and socialization consequent to it. In the horizontal concentration of the urban housing structure, the boundaries between public and private spaces are dissolved, resulting in what can be seen as common space. Situated neither in the private nor in the public realm, the social space of dwelling community proposed by Zloković seems to be pervaded by the notion of the "common", even in the sense of contemporary theoretical reading of the term.

Antonio Negri's critique of real socialism points precisely the distinctions between the private/public and the common, when he claims: "Real socialism ... confused the common with the public, that is, it reduced it to property of the State or to service of the State - a dispositif that was developed in all socialist and welfarist practice". ${ }^{16} \mathrm{He}$ continues to say that the common extends beyond the categories of private or public, to arrive at what he calls communal management. In Zloković's proposal, the formal system constructs the space of the communal, itself necessarily managed communally. The plan, as I read it, implies a social space of everyone together, and as Negri says, it isn't utopia. It is a vision of a collective dwelling practice of very specific Mediterranean cultural, geographical and climatic dispositions that structure it. 

by Joseph Davidson. London, MDCCLXXXV, pp. 212-3.

Digitalized by Google, available from World Wide Web, online, accessed August 28, 2010 : http://books.google.com/books?id=PuopAAAAYAAJ\&lpg=PA213\&ots=UIpkZ8IKd8\&dq=ferv et $\% 20$ opus\%20virgil\&pg=PA213\#v=onepage \&q=fervet $\% 20$ opus $\% 20$ virgil $\& \mathrm{f}=$ false boards, each marked up with the identification code "FERVET OPUS", not dated, in the architect's family private collection. Hitherto unpublished project, recently discovered in the family archives dates from the period 1947-8 (as established by this research). I am grateful to architect Đorđe Mojović, Milan Zloković's grandson, for sharing this project and providing its visual documentation. fakulteta, IV knjiga, Beograd: Univerzitet u Beogradu, 1957/58, p. 26 
Rebecca West, Black Lamb and Grey Falcon (1941, Penguin Books, 1969), p. 123

For further reading on Milan Zloković and his work in English language, see: Ljiljana Blagojević, Modernism in Serbia: The Elusive Margins of Belgrade Architecture, 1919-1941. Cambridge, Mass.: MIT Press in association with the Harvard University Graduate School of Design, 2003. For monographic study on Zloković in Serbian language, see: Zoran Manević, Zloković. Beograd: Institut za istoriju umetnosti i Muzej savremene umetnosti, 1989 (Cyrillic).

For the more detailed recounting of the events in Zloković's life at the end of World War One, see: Manević, Zloković.

Blagojević, Modernism in Serbia: The Elusive Margins of Belgrade Architecture, 1919-1941, p. 193

The yards were originally established by the German shipbuilding house Howaldts Werke of Kiel, and exploited by them for the initial ten years under the firm's name. In 1905, the firm of Danubius, Schönichen, Hartman from Budapest bought the shipyard, and changed its name to "Danubius". Being one of the principal builders for the imperial navy of Austro-Hungarian Empire, the shipyard secured financial support arranged through prominent banking institutions. On the initiative from two of the banks involved in the financing, a merger was arranged between "Danubius" and the Budapest foundry and machinery works "Ganz\&Co." In 1911, the shipyard was accordingly renamed "Ganz\&Co. Danubius", and in this period it ranked highly among leading European yards for building war ships. Shortly after the end of World War One, when Rijeka fell under Italian rule, the Shipyard was renamed "Cantieri Navali del Quarnero". Disfavoured within long-term state policies and exposed to fierce competition against other reputed Italian yards, the shipyard's prosperity started to decline. Upon the capitulation of Italy in 1943, Rijeka was seized by the German army, and until 1945 the shipyard went through total stagnation. Available from World Wide Web, online, accessed September 26, 2010: http://www.3maj.hr/cm/hrvatski/povijest. $\mathrm{htm}$,

"Zakon o Petogodišnjem planu razvitka narodne privrede FNRJ u godinama 1947-1951" (The Act on the Five-Year Development Plan of the National Economy of Federal People's Republic of Yugoslavia), published in: Borba (Belgrade), 1st May 1947, pp. 13-19 (Cyrillic).

In my study of the periodic publications of the period, primarily the magazine Arhitektura (Zagreb), I did not find any references to this competition, nor am I aware of any references in the secondary sources on the period. My ignorance notwithstanding, I should be grateful for any insights that might further this research.

Rail line Rijeka-Pivka (est. 1873) connecting Rijeka to rail line Vienna-Trieste.

Cf. Ljiljana Blagojević, Strategije modernizma u planiranju i projektovanju urbane strukture $i$ arhitekture Novog Beograda: period konceptualne faze od 1922. do 1962. godine. Ph.D. thesis, defended at the University of Belgrade - Faculty of Architecture, 2005 (Cyrillic).

Total: ca. 1,000 ground floor apartments with gardens (204 1-room, 746 2-rooms, and 52 3-rooms apartments), 480 apartments in six-floor-buildings, 20 apartments in ten-floor-apartment building, and 400 rooms (one or two beds) in "singles hotel".

"Real socialism (like Jacobinism before it) confused the common with the public, that is, it reduced it to property of the State or to service of the State - a dispositif that was developed in all socialist and welfarist practice. The project and the definition of the common consists instead in overcoming both the concept of the private and that of the public, in going beyond these two categories to arrive at communal management: it's everyone together, and it isn't a utopia." Antonio Negri, Goodbye Mr. Socialism, in conversation with Raf Valvola Scelsci. Translated by Peter Thomas (NY: Seven Stories Press, 2006), 38 